\title{
From Orality To Print: An Oraliterary Examination Of Efua T. Sutherland's The Marriage Of Anansewa And Femi Osofisan's Morountodun.
}

\author{
${ }^{1}$ Uwem Affiah, Ph.D, ${ }^{2}$ Ndubuisi Osuagwu, Ph.D \\ ${ }^{1,2}$ Department Of English And Literary Studies, University Of Calabar, Nigeria.
}

\begin{abstract}
African oral literature remains a veritable source of material for African literary drama through various means, ikncluding exploitation and adaptation. By so doing, besides the aesthetic benefits, present and future generations can learn, imbibe and practicalise the moral and social values of traditional African societies which we seem to badly require at this time of severe moral decadent. This essay shows the exploitation of indigenous African arts in terms of content and aesthetics by two prominent African dramatists, viz, Efua T, Sutherland of Ghana and Femi Osofisan of Nigeria.
\end{abstract}

Key Words: Oral tradition ( oral literature), exploitation, anaseseem, anansegoro, myth.

\section{Overview}

All over Africa, for centuries now, there has existed a rich oral tradition of story telling, rendition of songs, ritual dances and several traditional ceremonies and festivals. "If we accept the idea of literature as a creative text" (Okpewho 1992:3), then noting the creative embedded in the aforementioned as well as the way they appeal to our imagination and emotions, it immediately becomes clear to us that we are dealing with literature. The stories, songs, dances and traditional festivals were, as they still are today, an expression of the people's consciousness. As Ogude (1983) asserts, "literature in this context (is an) expression of people's consciousness in a social situation" (1).

Different cultures the world over, have developed what is today termed their 'modern' literature out of their traditional background giving rise to a situation where what “... was once only heard ... can now in addition be read ..." (Ogud1 983: 1). Indeed, classical Greek tragedy is known to have developed from the tradition of ancient Greek rituals and religious sacrifices.

In Africa " there has, indeed, been an increasing tendency on the part of modern African writers to identify with the literary tradition of their people in terms both of content and of technique" (Okpewho 1992: 293). A cursory mention of some examples will shed some light on the phenomenon.

The Sotho writer, B.M. Khatta's description of train (Kunene $1970: 150$ - 151) is all but a manifestation of his application of the Sotho praise tradition. As with Sotho praise poets, he mixes a heroic portrait of the train with a tone of protest.

The late Ugandan poet Okot P' Bitek is known thave "remained a staunch believer in the vitality of the oral traditions" (Okpewho 1992 : 302). All his songs, particularly song of Lawino, show his heavy reliance on his native Acoli tradition of the poetry of abuse.

From the Yoruba of western Nigeria, we have Daniel Fagunwa whose fine works of fiction, in addition to being written in Yoruba, are drawn from the tradition of hunters' tale which is a major sub-class of Yoruba oral narrative. Okpewho( 1992) asserts that Fagunwa's works “... are fundamentally indebted to the oral tradition in both matter and manner of narration" (305).

The incidents in Amos Tutuola's the The Palm - Wine Drinkard carry motifs which like in Yoruba oral tradition are familiar along the west coast of Africa. The magnitude of Tutuola's indebtedness to the oral tradition "forced Omolara Ogundipe-Leslie to declare Tutuola a borrower" (Okpewho 1992 : 307). OgundipeLeslie adds that Tutuola did not invent much in the Palm-Wine Drinkard.

We cannot but remember J.P. Clark's Ozidi Saga and most of Achebe's novels which draw heavily on the resources of the oral tradition.

Perhaps it is pertinent to state that the crossing of currents has not remained altogether one sided, from orality to print. An examination of the matter and manner of concert parties and traveling theatres show that they do transform material from written works into their oral dramatic performances. Take Ogunde's Israel in Egypt for an example. The play which explores the fortunes of a people under subjugation and oppression and which is a metaphor of the Nigerian colonial situation is no doubt, inspired and patterned along the lines of the biblical story of the Israelites in Egypt .

This essay is a study of the intrinsic relationship, the cross currents, between oral literature and modern African drama. The essay examines Efua T. Sutherland's The Marriage of Anansewa and Femi Osofisan's 
Morountodun in the light of this relationship and in the process validates the assertion that the vitality of oral literature for modern society still enjoys a rich currency. The essay shows that there is ample room for the exploitation of the resources of the oral tradition in the artistic pursuit of social, economic and political peace and equality in our continent nay our world today.

\section{Anansesem}

The word Anansesem literally translates to Ananse stories. Anansesem is the story - telling art of the Akan - speaking people of Ghana. Originally a domestic activity, it is known today to have been given full theatrical expression by some specialized, professional groups. The result of this is the presence today of established conventions for its practice. The word, Anansesem is used to refer to the body of stories and to the art. Dibba ( 1978 ) opines that Anansesem had "previously fulfilled certain community aesthetic, moral and cultural needs among the Akan - speaking people of Ghana" (2).

Sutherland herself throws some light on the practice when she says:

The stories are composed with performance demands in mind and in a number of different forms and styles.

Most are in a combination of narrative prose and a poetry which is meant to be sung or rhythmically recited on the basis of solo and choral response. Stories in the tradition are under content revision for renewal and development. Also, contemporary interest inspires the composition of completely new stories to replenish the repertoire. ( $1975: \mathrm{v}$-vi)

Anansesem seems to serve a dual purpose, namely: didactic and religious. It is used in instructing the younger generation in moral behaviour and social norms on the one hand and to explain phenomena which were otherwise inexplicable on the other. Some scholars posit, arguably though, that the preponderance of the formulae of recurrent songs is indicative of Anansesem originally being part of the ritual of exorcism and social purgation.

From this Akan story - telling tradition, Sutherland has evolved a tradition of modern drama practice which she calls Anansegoro.

\section{Basic Strands In The Nature Of Anansesem}

Succeeding scholars and critics have isolated and crystallized certain basic strands in the nature of Anansesem. They include the storyteller or narrator, music, dance, mime and praise - singing.

Sutherland (1975) sees the storyteller as " the owner of the story with a conventional right to know everything" (v). He is the overseer of the whole story and the commentator whose comments give insight into the events of the story. He ensures audience participation as well as imitates the songs. Like performance to oral literature, so is the storyteller to Anansesem - central and crucial.

Another basic strand in the nature of Anansesem is music. Whereas some scholars prefer to consider music, song, hand-clapping and gong - rhythm as separate and different strands, it would seem to me that it is better to see all of these as one strand which we can call music. Let me attempt to proffer reasons for this preference. Firstly, it ensures a small, neat and manageable number of strands. Secondly, and most importantly, if we accept music to be series of sounds, whether by instruments or voices, made in an exciting or pleasant way, it becomes apparent that handclapping gong - rhythm and songs can be accommodated under music. In Anansesem, the songs which are traditionally called Mbuogo are an integral part of the performance. Usually, they contain the central ideas of various episodes, offer opportunity for audience participation and break up the main action and offer some relief to both the storyteller and the audience while illustrating the actions of the story.

Dance, mime and praise-singling are used in varying degrees but usually to a lesser degree in comparative terms with the storyteller/narrator and music.

\section{Synopsis Of The Marriage Of Anasewa}

The Marriage of Anansewa does not adopt wholesale the traditional trickster tale format of friendship followed by agreement after which a contract is entered into and then one party breaches the contract (betrayal), a betrayal which is later discovered and which in turn leads to revenge and followed by an end of the friendship. Notwithstanding, it relies substantially and follows the traditional plot line of the ananse tales, a heritage of trickster tales among the Akan-speaking people of Ghana.

Ananse is broke and in financial difficulties. Even his daughter's school fees connot be paid as the family slips into misery. Inspired by a seeming desire to ameliorate the problem, Ananse enters into a secret pact with four chiefs, severally, promising each the hand of his daughter, Anansewa, in marriage. When Anansewa discovers the scheme she is alarmed but is persuaded by the cunning Ananse to cooperate so as to ensure the material well-being of the family. The scheme is a huge success as the suitors pour in cash and gifts. 
Matters come to a head when the four chiefs arrive severally to legalise the marriage and take the young woman home. Ananse comes up with a scheme, convinces his daughter to act dead while he sends messages to the four chiefs informing them of the death of Anansewa.

By their various reaction to Anansewa's 'death', the scheme produces the one most qualified to have her hand in marriage. Even a cursory reading of the play leaves the reader with no doubt about the playwright's indebtedness to the tradition of the oral narrative performance of Anansesem.

\section{From Orality To Print: The Marriage Of Anansewa And The Debt To Anansem.}

The theme of the play is drawn straight from the trickster tales of the Anansesem tradition. Its relevance in time, which emphasizes its contemporaneous image, again, underscores the relevance of oral literature even today. It answers the often asked question: which is more important? The sensibilities transmitted in a work of art or the mode of transmission?

In different communities different animals represent the trickster. In some communities it is the tortoise. In others it is the hare, and yet in others it is the spider. In the Anansesem tradition of the Akanspeaking people it is the spider. Whether the trickster be the tortoise or the spider, they manifest the same traits. They are all crafty, cunning, selfish, greedy, deceitful and conceited. George Kweku Ananse has a generous dose of these traits. These traits, in turn contribute to the development and realization of the theme: (modern) man's quest for materialism by hook or crook.

The entire play centers around the cunning, trickish Ananse. He is a crafty modern individual who converts every little opportunity into an illegitimate avenue to amass wealth. In the words of Dibba "it is with falsehoods solely that he manages his life" (1978:29). A Machiavellian figure with absolute faith in Machiavellianism, Ananse as an embodiment of the thematic concern of the play, represents modern man's approach to life be it in commerce, politics or socials.

In Anansesem, we all the time encounter a cunning Ananse applying illegitimate and unconventional means to smoothen his existence. In The Marriage of Anansewa we see 'modern' Ananse with 'modern' cunningness applying still illegitimate and unconventional means in pursuit of materialistic gains.

In moving from orality to print Sutherland had to be guided by the format of modern drama. This implies some modernization. The play is, thus, structured into acts - four acts in all. Sutherland employs some other elements to give the play contemporary appeal.

Anansewa is intelligent and educated. She attends a secretarial school, which was very much the vogue for young girls in the 1960s. Ananse is eager to go to church and show off his newly acquired wealth. This seems to be a sub-theme as Sutherland actually seems to pillory the nouveaux riche who ostentatiously flaunt their illgotten wealth. The dramatist refers to Miss Christina Yeboah (Christie) as a fashionable lady. Christie is indeed a sharp contrast to what is traditional. She uses affected language and serves, also, as a vehicle for the modernization of Ananse (the spider) as she sometimes calls him 'Georgie' or 'darling' or 'sweetie'. Ananse even avails himself of secretarial services and in so doing pushes his modernization further. In one of Anansewa's suitors, the "Chief whose name is mentioned in the ear" (Sutherland 1975:14), we possibly have the image of the military leadership of the 60s to the nineties. These contemporary elements are imperatives of modernizing the play but serve a functional purpose of promoting comic effect. Nonetheless, these elements do not detract from the traditional origin of the play.

Beyond the theme coming straight out of the trickster tradition, Aya and Ekuwa, Ananse's mother and aunt respectively, represent tradition. Spiritually and socially, Aya is traditional. She believes strongly in the outdooring ceremony which is the ritual representing the passage from girlhood to womanhood. Through Aya and Ekuwa, the playwright links the traditional with the modern and creates a balance between the two sensibilities.

Vincent (1975) contends that " drama is the supreme example of collaborative effort" (80). The Marriage of Anansewa is the outcome of a collaboration between oral and modern African drama. It seems the highpoint of this collaboration on the part of oral drama is the relocation of the storyteller to the Anansegoro format from the narrative format. Just as he is central to the action in Clark's The Ozidi Saga, so is he central to the action in Sutherland's The Marriage of Anansewa. We had earlier in this essay noted that he is the owner of the story. As is typical with the storyteller/narrator of the Anansesem, the storyteller in The Marriage of Anansewa controls all the events in the drama. He explains events, prepares us for future scenes, comments on the behaviours of characters, engages the actors and the audience and even participates in the action.

In the oral performance, which Anansesem is, the audience is actively involved. The text is not experienced and enjoyed in the cold comfort of one's room. The narrator carries along the audience, who are usually deeply involved in the process of performance and who expect both benefit and delight from the performance as much as the performer does. In The Marriage of Anansewa both the storyteller and Ananse try to carry the audience along. The audience on its part joins in singing and also make comments and other forms of contributions. 
Another significant aspect of Anansesem which has been intergrated into Sutherland's Anansegoro is the use of Mbuogo (songs). As in Anansesem, the songs provide an opportunity for the audience to get involved in the performance. The songs are an integral part of the stories and offer explanations or contain ideas manifest in episodes of the story or the entire story. The songs are also used to punctuate and ventilate the action.

For all that it is worth, for providing an opportunity for the extension of the limits of traditional art form to accommodate and express contemporary experiences and sensibilities, The Marriage of Anansewa is a good example of orality to print, of "a good drama (of) the supreme example of collaborative effort" between orality and print.

Let us now proceed to examine the movement from orality to print in the case of Osofisan's Morountodun. It is proper to begin with an understanding of the concept of myth

\section{The Moremi Myth}

Abanuka(1999) defines myth as "... a simple human attempt to explain in symbolic language the origin of the world, human discoveries and inventions, suffering and death..." (5). This definition implies that myth is a story invented to explain natural or historical events and occurrences. On his part, Okpewho writes that" the word myth has also frequently been used for describing a tale in which gods, or divinities recognized by a community of people (not just fairies or ordinary spirits) are the protagonists..." (1992:181).

The Encyclopedia Americana defines myth as "stories told as symbols of fundamental truths with societies having a strong oral tradition" (699). A point worthy of note in the last definition is the fact that myth is closely related to oral tradition.

Ruth Finnegan(1970) adds another element to the definition when she writes that myths are considered to be "truthful accounts of what happened in the remote past. They are accepted on faith ... taught to be believed; and can be cited as authority in answer to ignorance, doubt or disbelief" (361 - 362). From all these definitions, we can deduce that myths are, originally, oral narratives, serious and sacred, often with ritual backgrounds, having gods or men or monstrous creatures with both qualities as characters .

Scholars belonging to various schools of thought have tried to explain the relationship between myth and society. The functionalist scholars Emile Durheim and Bronislaw Malinowski assert that myths promote social solidarity and enhance integration. Myths provide an avenue for the transmission of culture, protection of cultural continuity and stabilizing the society.

For the creative artist, therefore, myth serves "as a means... (of) aiming for order and meaning in a skeptical age" (Feder 1971:4). Several creative writers including Clark in The Ozidi Saga, Soyinka in The Road and Death and the Kings Horseman and Rotimi in The gods Are Not to Blame have plotted their works against the background of traditional myths. Some of these myths are historical while others are romantic. Osofisan plots Morountodun against the background of the Yoruba myth of Moremi.

The Moremi myth has it that the people of lle-lfe suffered constant raids from their neighbours, the mysterious Igbo. All effort to contain the Igbo forces proved futile. The lfe people turned to their gods for assistance, but the gods failed them. Then, Moremi, wife of the Ife king decides to save her people. She releases herself to be taken away by the Igbo. She becomes their king's wife and is opportuned to learn their magic art. In due course she escapes and returns to lle-lfe with the secret of Igbo magic art. This she reveals to the lfe people who on account of it conquer the Igbos. However, in keeping with the terms of her covenant with Esinmirin before leaving lfe, she had to sacrifice her only son Oluorogbo to Esinmirin river.

Osofisan combines myth and history in Morountodun as he combines the myth of Moremi with the Agbekoya uprising of 1969. Osofisan draws the theme and the plot from the myth of Moremi but to remove the play from the realm of myth and ritual by weaving it around the Agbekoya peasant farmers uprising. This essay proceeds next to look at the playwright's indebtedness to myth in Morountodun.

\section{FROM OARALITY TO PRINT: MOROUNTODUN AND THE MYTH OF MOREMI}

Osofisan seems to cleverly select aspects of the myth of Moremi which are suitable for his purpose and applies them in crafting the play. This appears to conform to Echeruo's assertion that myth is an indispensable element that develops into drama through selective elaboration, re-enactment and reinterpretation. In Morountodun, Osofisan points out the need for self sacrifice. If people must evolve a better society then they must be ready to make sacrifices. Osofisan cites an actual occurrence in an effort to incite people suffering oppression to rise and revolt against the system. The allusion to historical reality is a way of rousing oppressed people to action by saying that it is possible to do it. It also means that Osofisan is saying that passivity, docility and complacency will not help.

In many ways, Titubi is fashioned after Moremi. After being goaded and humiliated by the Superintendent, Titubi volunteers to help end the revolution by arresting the leader. She emulates Moremi by allowing herself to be capture. Through Titubi's recall of the Moremi myth, Osofisan states that since the gods 
(in this case the oppressors) are indifferent to the plight of the oppressed, then the fate of the oppressed is in their own hands.

Osofisan continues his treatment of the theme of sacrifice as he makes Titubi to experience the degrading life of the poor as opposed to her normal luxury life. While in the camp, she experiences how the oppressed live and is appalled at the injustices they live with:

You know before this... I could never have believed that life was so unkind to anybody (Morountodun, 65).

And then she begins to ask questions:

... I began to ask questions. Questions. I saw myself growing up knowing no such suffering as these. With always so much to eat ... Yet here, farmers cannot eat their own products but must be content with wind in their stomach. And then when they return from the market, the tax man is waiting with his bill... it could not be just (Morotodun, 66).

These lead to her transformation:

... in our house we wake to the chorus of jingling coins. And when we sleep; coiled springs, soft foams and felt receive our bodies gently. But I have lived in the forest among simple folk; sharing their pain and anguish ... and I choose ... (Morotodun, 66).

Even as Titubi achieves Moremi's feat, she undergoes a metamorphosis. Having noted the injustice meted by the privileged class on the suffering masses, she opts to align with the oppressed to fight and end the injustice. Through the use of the Moremi myth, Osofisan shows that one needs to experience injustice and oppression to be able to understand and appreciate the predicament of the oppressed. That Titubi resurfaces as an agent of truth and justice gives hope.

Osofisan uses the Moremi myth to elucidate the moral motif in human struggle. Moremi was involved in a self-sacrificing struggle for legitimate communal peace. Titubi's metamorphosis is only proper for she ought to be on the side of truth and justice. Like Moremi, Titubi becomes a symbol of hope for the ailing society. Inherent in her change is an admission of the fact that no one can win an unjust war, and this much she admits herself.

Her marriage to Marshall who she initially sets out to capture and handcuff raises hope that some day the oppressors and the oppressed will become friends and equals. The marriage symbolizes the dismantling of the barrier between the rich and the poor, the oppressors and the oppressed. While handing over the gun to Marshall, she says: "Take the gun. Let a new life begin." This symbolizes the fact that one day, authority, power and government will change hands and go to the masses of the oppressed majority.

Another technique of the oral tradition used here is that of a storyteller/narrator as represented by the director. Through him the playwright conveys some of his massages. He is the chief source of enlightenment for the audience. He transcends the entire story and this is a quality of the folk narrator.

The episodic structure or method of "discontinuous episode", which allows the dramatist to suspend the progress of the story to allow for a re-enactment of aspects of the past is a story telling device of the oral tradition.

\section{Conclusion}

This essay opines that quite a generous amount of modern African drama is the secularization of traditional African ritual festivals and oral narratives. Oladele Taiwo(1967) corroborates this when he opines that the products and activities of traditional African communities and essential elements of folk values and heritage form the background on which written literature is based (39).

Indeed the Yoruba opera which signals the very beginning of modern drama in Nigeria draws its essential elements from the oral base of music and dance. From South Africa Leshoai(1978) reports that the theatre of black South Africa has had its root in traditional story-telling poetry, dances, songs, proverbs and riddles" (1150). And though Nazareth(1978) states that Mahood sees the kikuyu dance and the funeral dances of the Nyakyusa of Tanzania, East Africa, as 'pre-drama' (91), Bell-Gam concludes that the most frequently used folk arts by modern African dramatists can be summed up as rituals, proverbs, tales, riddles, costumes, masks, dance movement and superstition (1986:186).

The collaboration between orality and print is impressive and requires encouragement not only as a means of giving the oral tradition a rich currency but also to ensure that modern society benefits from the richness of our cultural heritage. 


\section{Works Cited}

[1] Abanuka, Bartholomew. Myth and the African Universe. Onitsha: Spiritan publications, 1999.

[2] Bell-Gam, Henry "Dramatic Dimensions of an Oral Form. The Aguri masquerade performance in Opobo." Nigerian Theatre Journal Vol. 2, Nos. 1-2, (1986): 181 - 190.

[3] Dibba, Ebou. Efua T. Sutherland: The Marriage of Anansewa. London: Longman Group Limited, 1978.

[4] Echeruo, Micheal J. C. "The Dramatic Limits of Igbo Ritual." Drama and Theatre in Nigeria: A Critical Source Book. Lagos: Nigeria Magazine, (1981): 136 - 148.

[5] Feder, Lillian. Ancient Myth in Modern Poetry. Princeton: Princeton University Press, 1971.

[6] Finegan, Ruth. Oral Literature in Africa. Nairobi: Oxfird University Press, 1970.

[7] Kunene, D. Heroic Poetry of the Basotho. Oxford: Clarendon Press, 1970

[8] Leshoai, B. L. "Black South African Theatre." Theatre in Africa. Ibadan: University Press, (1978): 112 -121.

[9] "Mythology." Encyclopedia Americana. 1981 ed.

[10] Nazarath, Peter. "East African Drama." Theatre in Africa. Ibadan: University Press Limited, (1978): 83 - 96.

[11] Ogude, S. E. Genius in Bondage: A Study of the Origins of African Literature in English. Lle - lfe: University of lfe Press, 1983.

[12] Ogundipe-Leslie, Omolara. "The Palm - Wine Drinkard: A Reassessment of Amos Tutuola." Critical Perspectives on Amos Tutuola. London Heinemann, (1975): 104 - 116.

[13] Okpewho, Isidore. African Oral Literature: Backgrounds, Character, and Continuity. Bloomington and Indianapolis: Indiana University Press, 1992

[14] Osofisan, Femi. Morountodun and Other Plays. Ibadan: Longman Limited, 1982.

[15] Sutherland, Efua T. The Marriage of Anansewa. London: Longman Group Limited, 1975.

[16] Taiwo, Oladele. An Introduction to West African Literature. Lagos: Thomas Nelson Nigeria Limited, 1967.

[17] Vincent, Theo. "Theatre and Audience in Nigeria." Black Orpheus Vol. 4 No. 1. Lagos: Lagos University Press, (1975): 75 - 87 